\title{
Effectief sturen op output in het openbaar bestuur
}

\author{
Rick Anderson en Henk Klaassen
}

SAMENVATTING Outputsturing wordt de laatste jaren steeds meer als ideale sturingsvorm gezien binnen het openbaar bestuur. Onderzoek naar de effecten van deze sturingsvorm is echter nog niet systematisch verricht, terwijl de geluiden uit de praktijk cynischer worden.

Dit artikel geeft een verslag van een onderzoek dat is verricht naar de effectiviteit van outputsturing binnen gemeenten. Bezien is, hoe effectief de gehanteerde sturingsvorm is en welke contextvariabelen deze effectiviteit beïnvloeden.

Uit het onderzoek blijkt, dat de contextvariabelen niet altijd een eenduidige impact hebben op de gerealiseerde effectiviteit. Het onderzoek wijst verder uit, dat tussentijdse sturing en processturing de effectiviteit niet altijd bevordert.

\section{RELEVANTIE VOOR DE PRAKTIJK Zoals iedere vorm van sturing informatie nodig heeft} en oog moet hebben voor de context, veronderstelt outputsturing dat informatie over output voorhanden is en dat aangesloten wordt op de context om outputsturing vorm te geven. Inmiddels zijn het gebruik en de kwaliteit van outputinformatie redelijk onderzochte terreinen en zijn tevens contextvariabelen getraceerd die van invloed zijn op de effectiviteit van outputsturing. Eerdere onderzoeken laten zich niet uit over de manier waarop outputsturing precies moet worden vormgegeven. Outputsturing kan echter verschillende vormen aannemen, zo wordt in dit artikel duidelijk. Gesteld kan worden dat sommige vormen effectiever zijn dan andere vormen, ongeacht de context.

\section{Inleiding}

Hoewel relatief veel onderzoek is gedaan naar het gebruik van prestatie-indicatoren binnen het openbaar bestuur, is nog niet veel bekend over de manier waarop outputsturing binnen het openbaar bestuur vormgegeven moet worden. Dit is opmerkelijk, omdat vanuit de praktijk de geluiden over outputsturing niet altijd positief zijn (Ter Bogt, 2008, p. 39; Bordewijk en Klaassen, 2010). Auteurs wekken soms de indruk dat slechts één vorm van outputsturing voorhanden is en dat deze vorm slechts effectief kan zijn onder bepaalde condities. De vraag rijst echter in hoeverre verschillende vormen van outputsturing te onderscheiden zijn en of sommige vormen van outputsturing effectiever zijn dan andere. Dit artikel betreft een onderzoek naar de effectiviteit van outputsturing binnen Nederlandse gemeenten. Centraal daarbij staat de vraag welke vorm van outputsturing als het meest effectief kan worden aangemerkt en hoe sterk de invloed van de context daarbij is. Dit artikel gaat allereerst in op de problemen die de introductie van outputsturing binnen het openbaar bestuur ondervindt. Vervolgens zullen een aantal contextfactoren en sturingsvormen worden uitgewerkt, waarna een opzet van onderzoek wordt gepresenteerd. Na de analyse van de onderzoeksresultaten, sluit het artikel af met enkele conclusies.

\section{Outputsturing als nieuw ideaal}

Om het begrip outputsturing te kunnen duiden, lijkt het raadzaam eerst in te gaan op de bredere sturingsvorm, waarbinnen outputsturing geplaatst kan worden; prestatiemanagement. Prestatiemanagement kan gedefinieerd worden als een sturingsvorm waarbij informatie met betrekking tot prestaties wordt gebruikt voor besluitvorming (Van Dooren e.a., 2010, p. 30; Moynihan, 2008, p. 5). De besluitvorming kan zich daarbij richten op het beïnvloeden, verbeteren en beheersen van processen of op de verantwoording over het procesverloop (Van Dooren e.a., 2010; Van Elsacker e.a., 2008, p. 58; Bouckaert en Halligan, 2008, p. 2; Pollitt en Bouckaert, 2004). Management by objectives, outputsturing, resultaatgericht management en performancemanagement zijn volgens deze gedachtelijn aan te merken als vormen van prestatiemanagement. In dit artikel wordt onder outputsturing een sturingsvorm verstaan waarbij de productie van output leidend is voor de besluitvorming. De combinatie van output- en inputsturing wordt ook wel outputbudgettering, outputfinanciering of prestatiebekostiging genoemd. Outputbudgettering betreft een budgettering van de output gegeven de kostprijs per eenheid van de output. Outputbudgettering kan dus als een scherpere vorm van outputsturing worden aangemerkt, waarbij naast output tevens op budget (input) gestuurd wordt. Outputbudgettering wordt in dit onderzoek gedefinieerd als een sturingsvorm die gericht is op het aantal te produceren eenheden product en op de kostprijs van dat product. 
Outputsturing en doelmatigheidsverbetering zijn belangrijke thema's binnen New Public Management, een managementfilosofie die zonder twijfel een grote invloed heeft gehad op het denken over management binnen het Nederlandse openbaar bestuur (Van Elsacker e.a., 2008; Groot en Budding, 2008; Caiden, 2010; Ter Bogt, 2008). Het definiëren van output en het maken van afspraken over de productie en de realisatie van deze output, vormen centrale thema's binnen het New Public Management (Groot en Budding, 2008; Hood, 1991; Pollitt en Bouckaert, 2004; Bozeman, 2007). "Managing performance forms the core of public management, especially New Public Management", stellen Bouckaert en Halligan (2008, p. 13). New Public Management beoogt niet alleen output te identificeren en doelmatigheid te optimaliseren, maar tevens processen te decentraliseren, terwijl eveneens het planning-en-controlinstrumentarium aangepast zal moeten worden (Van Elsacker e.a., 2008; Terry, 1998; Hood, 1991; Hood, 1995; Pollitt en Bouckaert, 2004; Ter Bogt, 2008; Bozeman, 2007). Door de beoogde output concreet te formuleren en de besluitvorming en bekostiging te baseren op de productie van deze output, wordt het decentrale management de mogelijkheid en bevoegdheid gegeven om naar eigen inzicht de desbetreffende processen in te richten, terwijl dat management tevens verantwoordelijk wordt gehouden voor de geleverde output (Pollitt, 1993; Ter Bogt 2008). Deze combinatie van bevoegdheid en verantwoordelijkheid zou de doelmatigheid van het procesverloop binnen het openbaar bestuur kunnen bevorderen, zo is de gedachte.

Sturing op output is niet altijd even succesvol geïmplementeerd binnen het openbaar bestuur, mede vanwege de knelpunten die zich kunnen voordoen bij een dergelijke sturingsvorm (Klaassen e.a., 2010; Anderson, 2006; Van Dooren e.a., 2010; Hood en Peters, 2004). De problemen om het begrip doelmatigheid daadwerkelijk vorm te geven in de praktijk van het openbaar bestuur zijn namelijk talrijk (Borderwijk en Klaassen, 2000).

Gewezen wordt in dit verband op knelpunten van technische aard. Zo is de beoogde output vooraf niet altijd bekend, of kan deze moeilijk worden geconcretiseerd (Anderson, 2006; Hood en Peters, 2004). De koppeling tussen input en output is binnen overheidsorganisaties soms onduidelijk (Christiaens en Rommel, 2008). Daarnaast hanteren verschillende organisaties doorgaans verschillende vormen van kostenverbijzondering, met als gevolg dat een interorganisatorische vergelijking niet goed gemaakt kan worden. Het gevolg daarvan is, dat het soms lastig is een valide norm voor de desbetreffende outputinputverhouding op te stellen.

Daarnaast kan weerstand ontstaan indien men de doelmatigheid van werken binnen de publieke sector tracht te traceren en te analyseren, zeker als dit gekoppeld wordt aan bekostiging of zelfs bezuiniging (Klaassen e.a., 2010).
Zo worden jaarrekeningen bijvoorbeeld bewust te laat ingeleverd om het systeem te frustreren (Klijn e.a., 2006). Verder wordt soms gewezen op ongewenste neveneffecten die kunnen ontstaan als medewerkers zich enkel gaan richten op datgene wat gebudgetteerd en genormeerd wordt (Aardema, 2005; Pollitt, 1993; Brignall en Modell, 2000; Van Dooren e.a., 2010; Hood en Peters, 2004). Essentiële taken die niet in het bekostigingssysteem zijn opgenomen kunnen dan blijven liggen. Daarnaast ontwikkelen medewerkers onder een dergelijk systeem vaak strategieën die erop gericht zijn stress en werkdruk te mijden met als gevolg dat lichte dossiers sneller worden opgepakt dan zware dossiers (Herweijer, 2010).

Knelpunten kunnen ook bestuurlijk en beleidsmatig van aard zijn. Zo wordt het neutrale karakter van outputbudgettering door sommige auteurs in twijfel getrokken. Gewezen wordt dan op het gevaar dat niet alleen het beheer en de organisatie veranderen als gevolg van outputbudgettering, maar ook de inhoud van het gevoerde beleid (De Bruijn, 2001). De beoogde marktwerking wordt niet altijd gerealiseerd (Herweijer, 2010), terwijl soms juist te veel interne concurrentie ontstaat. Verder is het lastig om prestaties en activiteiten scherp te formuleren en vergt het niet toekennen van budget (als de prestaties niet geleverd zijn) een zekere vastberadenheid van bestuurders (Herweijer, 2010). Bestuurders vinden het niet altijd makkelijk om zich tot de hoofdlijnen te beperken die in het concept van sturen op output vervat liggen en hebben de neiging toch weer met gedetailleerde procesrichtlijnen aan de gang te gaan (In't Veld en Van der Knaap, 1994, p. 68; Hood en Peters, 2004; Pollitt e.a., 1999). Werken met resultaatverantwoordelijke eenheden maakt het openbaar bestuur daarnaast soms zeer onoverzichtelijk (Hood en Peters, 2004).

Tot slot zijn knelpunten van facilitaire aard te onderscheiden. Het noodzakelijke outputgeoriënteerde informatiesysteem komt in de praktijk niet altijd van de grond en de informatie heeft niet altijd betrekking op de daadwerkelijke prestaties (Bordewijk en Klaassen, 2000; Van Helden en Johnsen, 2002; Ter Bogt, 2004; Van Dooren e.a., 2010, p. 159 e.v.; Ter Bogt, 2008). De informatie is doorgaans kwantitatief van aard, terwijl prestaties zich hooguit kwalitatief laten duiden (Anderson, 2006). Sommige organisaties introduceren New Public Management met als voornaamste reden om niet ouderwets te lijken en met de tijd mee te gaan (Ter Bogt, 2008, p. 33; Moynihan, 2008, p. 60-68). Soms wordt zelfs gesteld dat outputsturing eigenlijk meer is op te vatten als een modeverschijnsel en slechts een symbolische waarde heeft (Ter Bogt, 2008, p. 43). Tot slot valt niet te verwachten dat iedereen direct begrijpt wat het nieuwe systeem inhoudt en hoe het werkt (Klijn e.a., 2006).

Mede door de bovenstaande knelpunten levert outputsturing niet altijd het gewenste resultaat op (Caiden, 2010; 
Groot en Budding, 2008; Ter Bogt, 2008; Blank, 2010). Van Dooren e.a. (2010, p. 178) betrekken zelfs het standpunt dat decentralisatie weliswaar tot positieve effecten kan leiden, maar dat outputsturing op zichzelf doorgaans juist tot negatieve effecten leidt.

\section{De factoren die van invloed zijn op de effectiviteit van outputsturing}

Verschillende auteurs onderscheiden verschillende sturingsvormen (In 't Veld en Van der Knaap, 1994; Anderson, 2006). De keuze voor een bepaalde sturingsvorm wordt daarbij ingegeven vanuit de context. Al naargelang een bepaalde factor of omstandigheid zich voordoet kan dan voor een bepaalde sturingsvorm gekozen worden.

Auteurs zijn welhaast unaniem in de stelling dat de mate waarin overeenstemming en duidelijkheid over de gewenste output en de mate waarin inzicht in de causaliteit tussen input, proces, output en effect ${ }^{1}$ bestaat, twee zeer bepalende factoren zijn voor het succes van outputsturing (Anderson, 2006; Van Helden en Johnsen, 2002; Van Elsacker e.a., 2008, p. 57; Merchant en Van der Stede, 2003). De mate waarin output geïdentificeerd en eenduidig geformuleerd kan worden, wordt eveneens van belang geacht voor een succesvolle toepassing van outputsturing (Hood en Peters, 2004). Van Elsacker e.a. (2008, p. 67) voegen hier nog de politieke gevoeligheid als factor aan toe, een factor die in de literatuur niet altijd de nodige aandacht heeft gekend. Deze auteurs verwachten een 'strakkere' vorm van sturing als de politieke gevoeligheid groter wordt. Overigens kan ook betoogd worden dat men op een hoger aggregatieniveau gaat sturen als manier van indekken, naarmate de politieke gevoeligheid groter wordt.

De meeste auteurs geven aan, dat invoeren van outputsturing een grondige kennis vereist van het desbetreffende proces (Klaassen e.a., 2010). Een systeem van outputsturing zal daarnaast ook zeer veel oog moeten hebben voor de context van het desbetreffende proces (Van Dooren e.a., 2010; Whalen, 1991). Verder heeft outputsturing enkel zin, als de verantwoordelijkheid voor de procesvoering wordt gedecentraliseerd richting de decentrale verantwoordelijken en als heldere afspraken worden gemaakt over de te leveren prestaties.

De gedachte rijst dat gezocht moet worden naar een vorm van outputsturing die rekening houdt met de specifieke context en die de decentrale agenten de mogelijkheid biedt processen naar eigen inzicht in te richten en uit te voeren. In dit verband wijzen veel van de voornoemde auteurs op het belang van contextvariabelen voor de effectiviteit van outputsturing. Minder aandacht wordt besteed aan het feit dat verschillende vormen van outputsturing bestaan, waarbij de ene vorm de opdrachtnemer meer vrijheidsgraden geeft dan de andere vorm. De vraag blijft dan open in hoeverre contextvariabelen nu bepalend zijn voor de effectiviteit van outputsturing of dat effectiviteit mede bepaald wordt door de vorm van outputsturing waarvoor geopteerd wordt.

\section{Onderzoeksopzet}

Zoals gesteld is outputsturing een sturingsvorm waarbij de productie van output leidend is voor de besluitvorming. Dit impliceert dat afspraken gemaakt worden over deze output en dat wordt bezien in hoeverre deze output geleverd wordt. De combinatie van output-inputsturing is te zien als een scherpere vorm van outputbudgettering, waarbij de bekostiging afhankelijk wordt gemaakt van de productie van output. Ook kan men outputsturing combineren met processturing. Outputsturing kan men vooraf, tussentijds of achteraf toepassen of men kan opteren voor een combinatie. Ten behoeve van dit onderzoek worden twee sturingsvariabelen onderscheiden: ${ }^{2}$ het aangrijpingspunt van sturing (input, proces, output of effect) en het tijdstip van sturing (vooraf, tussentijds of achteraf). Vrijwel iedere combinatie van sturingsvariabelen is denkbaar, maar sommige combinaties zijn realistischer dan andere.

Het is nu de vraag welke vorm van outputsturing de meest effectieve is en welke contextfactoren deze effectiviteit bepalen. Zoals beschreven worden door verschillende auteurs contextfactoren in stelling gebracht die bepalend kunnen zijn voor de effectiviteit van outputsturing. Daarbij springen vier factoren in het oog. Ten eerste wordt aangegeven dat de mate van overeenstemming over de te bereiken output een zeer bepalende factor is voor de uiteindelijke effectiviteit van outputsturing (Van Helden en Johnsen, 2002). Daarnaast dient men inzicht te hebben in het transformatieproces en dient men de causale verbanden binnen dat proces te doorzien, wil outputsturing kans van slagen hebben. Verder dient de output eenduidig te identificeren te zijn en dient men heldere afspraken te maken over de output die gerealiseerd moet worden. De vierde factor wordt minder vaak opgevoerd vanuit de literatuur. Het betreft de politieke gevoeligheid.

Effectiviteit van sturing beslaat een breed terrein. In essentie verwijst sturing naar de manier waarop besluiten worden genomen en afwegingen worden gemaakt. Effectiviteit van outputsturing kan dan verwijzen naar de mate waarin allocatiemogelijkheden ten aanzien van output inzichtelijk zijn gemaakt. Volgens deze gedachte is een vorm van outputsturing effectiever, naarmate deze vorm het allocatieproces bevordert in termen van inzicht, draagvlak, kwaliteit, etc. Deze opvatting over de functionaliteit van outputsturing is echter nog te breed om een operationalisatie mogelijk te maken. Een verenging in functionaliteit is dus noodzakelijk. Ten behoeve van dit onderzoek wordt expliciet de effectiviteit van sturen door een opdrachtgever richting een opdrachtnemer bezien en in relatie gebracht met de output die de opdrachtnemer 
moet leveren. Effectiviteit wordt dan beoordeeld vanuit de optiek van de opdrachtgever.

Als opdrachtgevende organisatie is gekozen voor Nederlandse gemeenten. Nederlandse gemeenten sturen organisatieonderdelen op verschillende manieren aan, maar het gebruik van outputindicatoren is daarbij de laatste jaren gebruikelijk (Van Elsacker e.a., 2008, p. 54; Van Helden en Johnsen, 2002; Bouckaert en Halligan, 2008, p. 90). Het object van onderzoek is de vorm van outputsturing die het gemeentelijk concern hanteert richting een interne decentrale afdeling.

De gedachte is nu, dat de uiteindelijke kostprijs die de gemeente betaalt voor de geleverde output lager zal zijn, indien een juiste vorm van outputsturing gehanteerd wordt. Effectiviteit wordt dus vertaald naar de kostprijs die de gemeente betaalt voor een eenheid geleverde output. $\mathrm{Nu}$ blijkt het traceren van de eigenlijke kostprijs voor ambtelijke output, en met name het interorganisatorisch vergelijken van de verschillende kostprijzen, een lastige aangelegenheid. Dit laatste probleem kan deels ondervangen worden door niet zozeer naar de kostprijs, maar eerder naar de productieve uren te kijken die benodigd zijn om de output te realiseren. Uiteraard blijft de geleverde output per gemeente in termen van kwaliteit moeilijk vergelijkbaar. Dit probleem is ten dele te verhelpen door een proces te selecteren waarvan de output kwalitatief door een externe partij beoordeeld wordt of kan worden. Effectiviteit wordt dan gedefinieerd als de verhouding tussen een eenheid product en het aantal productieve uren dat nodig is voor de totstandkoming van dit product. Hoe lager het aantal productieve uren, hoe hoger de effectiviteit.

Om de invloed van de contextvariabelen beter in beeld te brengen, worden twee gemeentelijke processen in het onderzoek meegenomen, die naar verwachting verschillend scoren op de contextvariabelen. De processen moeten idealiter in intern beheer worden uitgevoerd en er moet sprake zijn van outputsturing met betrekking tot de processen. Tot slot zal de output van deze processen kwalitatief beoordeeld moeten worden door een derde partij, om de kwaliteit enigszins te kunnen vergelijken. Gekozen is voor de behandeling van een bouwvergunningaanvraag en voor de totstandkoming van een structuurvisie. ${ }^{3}$

Van de 57 gemeenten die aan het onderzoek hebben deelgenomen, ${ }^{4}$ worden er 30 doorgelicht op het proces van bouwaanvraagbehandeling en 27 op het proces van de structuurvisie. Alle 57 gemeenten hanteren vanuit het concern een vorm van outputsturing met betrekking tot de desbetreffende processen. De analyse richt zich in eerste instantie op de verschillen per proces, dus de verschillende vormen van outputsturing, context en effectiviteit binnen het proces bouwvergunningen of binnen het proces structuurvisie. Omdat geen vergelijking wordt aangegaan tussen bouwvergunningen en structuurvisies, kan geopteerd worden voor verschillende gemeenten.

Het onderzoek maakt gebruik van gestructureerde interviews die zijn afgenomen bij de opdrachtgevende ambtenaren op concernniveau en de opdrachtnemende medewerkers of managers op decentraal niveau. Daarnaast is gebruikgemaakt van een documentenanalyse om bijvoorbeeld de ingezette ambtelijke capaciteit te traceren en om de aangegeven sturingsrelatie te verifiëren. Het onderzoek heeft plaatsgevonden in het najaar van 2010, maar betreft het begrotingsjaar 2009.

Zoals gesteld verwijst het begrip effectiviteit in dit onderzoek naar de kostprijs die de gemeente moet betalen voor een eenheid geleverde output. Voor het proces bouwaanvraagbehandeling is deze eenheid output dan een beschikking die wordt afgegeven op een bouwaanvraag van de reguliere categorie. Voor de totstandkoming van de structuurvisie is een eenheid output gedefinieerd als de structuurvisie zelf, zoals deze wordt aangeboden aan de gemeenteraad. De kostprijs wordt vertaald naar het aantal productieve uren dat ingezet moet worden om een eenheid output tot stand te brengen.

Outputsturing kan geoperationaliseerd worden naar de mate waarin het gemeentelijk concern afspraken maakt met het organisatieonderdeel over deze output en dit onderdeel aanspreekt op de realisatie van deze output. De scores op deze sturingsvariabele komen als volgt tot stand. Bezien wordt, waar de afspraken tussen het gemeentelijk concern en het organisatieonderdeel betrekking op hebben. Als afspraken enkel over het budget worden gemaakt, kan gesproken worden over inputsturing. Afspraken over het aantal te behandelen aanvragen en over de oplevering van de structuurvisie worden daarentegen als vormen van outputsturing aangemerkt. Als het concern zich uitlaat over de manier waarop bouwaanvragen behandeld moeten worden en de structuurvisie vormgegeven moet worden, legt zij het aangrijpingspunt bij het proces. Uiteraard zijn ook combinaties mogelijk.

Het tijdstip van sturing kan plaatsvinden voordat het begrotingsjaar is begonnen, na verloop van het jaar, maar ook tussentijds. Dit laatste wordt ook wel monitoring genoemd. Ook hier zijn combinaties mogelijk. Ieder contact (fysiek, per mail of telefonisch) tussen het concern en het organisatieonderdeel waarbij de output, het proces of de input object van gesprek is, kan als een sturingsmoment worden aangemerkt. Daarbij dient sturing vooraf 
plaats te vinden voordat het begrotingsjaar van start is gegaan (dus voor 1 januari 2009), sturing achteraf vindt plaats na 31 december 2009 en iedere sturing tussen deze twee data wordt aangemerkt als tussentijdse sturing.

De mate waarin overeenstemming bestaat over de te realiseren output wordt getraceerd aan de hand van de respons op de vraag welke output nu bereikt moet worden met het desbetreffende proces. Naarmate het concern en de afdeling hierop verschillend antwoorden, neemt de overeenstemming af en vice versa. Het inzicht in het transformatieproces wordt achterhaald door de respondenten een globaal stroomschema van het proces te laten uittekenen. Naarmate de respondent meer interveniërende variabelen weet aan te geven, neemt zijn of haar inzicht toe. Het gaat hier overigens om het inzicht dat bij de opdrachtgever (het concern) bestaat. Verder kan de output meer of minder eenduidig worden omschreven en hiertoe wordt de omschrijving beoordeeld op specificiteit, meetbaarheid en tijdgebondenheid. Tot slot wordt de politieke gevoeligheid getraceerd aan de hand van de inschatting die op concernniveau wordt gemaakt.

Verwacht kan worden dat een lage score op de contextvariabelen een negatieve invloed heeft op de effectiviteit van outputsturing. Zo is outputsturing niet goed mogelijk naarmate minder overeenstemming en minder inzicht in het proces bestaat en naarmate de output minder goed geïdentificeerd wordt. Ook zal de politieke gevoeligheid niet bijdragen aan een effectieve outputsturing. Vanuit deze gedachte kunnen de eerste vier hypothesen geformuleerd worden.

H1 Sturing op output wordt effectiever naarmate meer overeenstemming bestaat over de output die geleverd moet worden.

$\mathrm{H}_{2}$ Sturing op output wordt effectiever naarmate een beter inzicht in het desbetreffende proces bestaat.

$\mathrm{H}_{3}$ Sturing op output wordt effectiever naarmate de output meer eenduidig wordt geformuleerd.

$\mathrm{H}_{4}$ Sturing op output wordt effectiever naarmate het proces minder politiek gevoelig is.

Een effectieve vorm van outputsturing zal naar verwachting gecombineerd moeten worden met inputsturing, maar juist niet met processturing, gelet op de waarschuwingen die op dit punt worden afgegeven door bijvoorbeeld In 't Veld en Van der Knaap (1994). Aan de hand hiervan kan de volgende hypothese worden geformuleerd:

H5 De effectiviteit van outputsturing neemt af naarmate zij gecombineerd wordt met processturing.

Ten aanzien van het tijdstip van sturing kan worden opgemerkt dat in het Besluit Begroting en Verantwoording, dat voor $g$ emeenten van toepassing is, de wenselijkheid wordt aangegeven van tussentijdse sturing (monitoring). Sturing vooraf en achteraf wordt doorgaans als noodzakelijk aangemerkt om ineffectiviteit te voorkomen, maar sturing tussentijds optimaliseert effectiviteit daadwerkelijk. Ook vanuit de literatuur op het gebied van planning en control wordt gewezen op de wenselijkheid van tussentijdse sturing (Anderson, 2006).

H6 Sturing ex ante en ex post is noodzakelijk om ineffectiviteit te voorkomen.

$\mathrm{H} 7$ Tussentijdse sturing verhoogt de effectiviteit van outputsturing.

\section{Resultaten en analyse}

De resultaten van onderzoek zijn opgenomen in bijlage I. De onderstaande tabellen kunnen per hypothese worden gepresenteerd. Gelet op de beperkte omvang van de steekproef, worden de hypothesen verdelingsvrij getoetst (Mann Whitney U-Test). Het gaat hier om een non-parametrische toets, welke uitgaat van een ranking en dus niet van de veronderstelling dat het gemiddelde van de steekproef een normale kansverdeling volgt. Naarmate meer productieve uren nodig zijn, komt een gemeente hoger in de ranking. Een hogere ranking impliceert dus een lagere effectiviteit van outputsturing.

In tabel 1 wordt voor beide gemeentelijke producten de relatie weergegeven tussen de mate van overeenstemming over de output en de effectiviteit van de outputsturing (weergegeven in een gemiddelde ranking per categorie, zie boven). Uit deze tabel blijkt, dat bij bouwvergunningen de effectiviteit van outputsturing aanmerkelijk groter is als de overeenstemming over de output ook groot is, terwijl dit voor structuurvisies in veel mindere mate geldt. Sterker zelfs: het aantal productieve uren dat wordt ingezet om een structuurvisie vorm te geven, wordt groter naarmate de overeenstemming over de output groter is. Wellicht vergt het verkrijgen van overeenstemming eveneens capaciteit. Het verband bij structuurvisies is overigens niet significant $(>0,05)$. Bij het proces van bouwaanvragen kan $\mathrm{H}_{1}$ dus bevestigd worden, bij structuurvisies niet.

In tabel 2 wordt de relatie tussen de mate van inzicht en de effectiviteit van de outputsturing in beeld gebracht. Bij structuurvisies neemt het aantal benodigde uren in eerste instantie af naarmate het inzicht toeneemt, daarna weer wat toe. Bij bouwvergunningen neemt het aantal benodigde uren in eerste instantie toe, daarna juist weer af.

Tabel 1 De relatie tussen de overeenstemming over output en de effectiviteit van outputsturing (H1)

\begin{tabular}{|l|l|l|}
\hline Overeenstemming over output & Bouwvergunningen & Structuurvisies \\
\hline Laag (mean rank) & 19,8 & 12,4 \\
\hline Hoog (mean rank) & 11,8 & 15,8 \\
\hline Asymp. Sig, Mann Whitney $(p<0.05)$ & 0,012 & 0,264 \\
\hline N & 30 & 27 \\
\hline
\end{tabular}


Tabel 2 De relatie tussen inzicht in het proces en de effectiviteit van outputsturing (H2)

\begin{tabular}{|l|l|l|}
\hline Inzicht in het proces & Bouwvergunningen & Structuurvisies \\
\hline Laag (mean rank) & 17,3 & 16,8 \\
\hline Gemiddeld (mean rank) & 19,6 & 10,2 \\
\hline Hoog (mean rank) & 11,0 & 14,6 \\
\hline $\begin{array}{l}\text { Asymp. Sig, Mann Whitney } \\
(p<0.05)\end{array}$ & 0,064 & 0,176 \\
\hline N & 30 & 27 \\
\hline
\end{tabular}

Deze relaties zijn echter beide niet significant. $\mathrm{H}_{2}$ kan in ieder geval niet bevestigd worden.

Het verband tussen een eenduidige formulering van de output en de effectiviteit van de outputsturing is volgens tabel 3 tegengesteld aan de verwachting. Bij beide processen neemt de benodigde capaciteit juist toe naarmate de eenduidigheid van outputformulering toeneemt. Ook hier vereist een zekere mate van eenduidigheid misschien de nodige capaciteit. $\mathrm{H}_{3}$ kan voor bouwaanvragen en structuurvisies dus niet bevestigd worden.

In tabel 4 wordt de relatie weergegeven tussen de politieke gevoeligheid en de effectiviteit van outputsturing. Bij bouwvergunningen zijn in eerste instantie meer productieve uren nodig, naarmate de politieke gevoeligheid toeneemt, maar neemt dit aantal vervolgens weer af. Dit verband is niet significant. Bij structuurvisies neemt het aantal benodigde uren significant toe, naarmate de politieke gevoeligheid toeneemt. $\mathrm{H}_{4} \mathrm{kan}$ dan ook alleen voor structuurvisies bevestigd worden.

Tabel 5 brengt de relatie in beeld tussen de effectiviteit van outputsturing en de aanwezigheid van processturing. De hypothese daarbij was, dat de effectiviteit van outputsturing zou afnemen, als zij gecombineerd zou worden met processturing. Voor beide processen geldt, dat significant meer productieve uren nodig zijn, als outputsturing gecombineerd wordt met processturing. Voor bouwaanvragen en structuurvisies kan $\mathrm{H}_{5}$ worden bevestigd.

Tabel 6 laat de relatie zien tussen de aanwezigheid van sturing ex ante en ex post enerzijds en de effectiviteit van

Tabel 3 De relatie tussen een eenduidige formulering van de output en de effectiviteit van outputsturing (H3)

\begin{tabular}{|l|l|l|}
\hline $\begin{array}{l}\text { Eenduidige } \\
\text { formulering output }\end{array}$ & Bouwvergunningen & Structuurvisies \\
\hline Laag (mean rank) & 8,7 & 12,8 \\
\hline Gemiddeld (mean rank) & 15,8 & 12,9 \\
\hline Hoog (mean rank) & 19,8 & 16,3 \\
\hline $\begin{array}{l}\text { Asymp. Sig, Mann Whitney } \\
(p<0.05)\end{array}$ & 0,021 & 0,573 \\
\hline N & 30 & 27 \\
\hline
\end{tabular}

Tabel 4 De relatie tussen politieke gevoeligheid en de effectiviteit van outputsturing $(\mathrm{H} 4)$

\begin{tabular}{|l|l|l|}
\hline Politieke gevoeligheid & Bouwvergunningen & Structuurvisies \\
\hline Hoog (mean rank) & 12,4 & 17,7 \\
\hline Gemiddeld (mean rank) & 18,9 & 11,7 \\
\hline Laag (mean rank) & 13,6 & 2,3 \\
\hline $\begin{array}{l}\text { Asymp. Sig, Mann Whitney } \\
(p<0.05)\end{array}$ & 0,166 & 0,005 \\
\hline N & 30 & 27 \\
\hline
\end{tabular}

outputsturing anderzijds. Bij een ex-ante- en ex-poststuringsvorm neemt bij beide processen het aantal benodigde productieve uren af, maar niet significant. H6 kan dan ook via deze toets niet bevestigd worden voor de onderzochte processen.

Tabel 7 geeft de relatie weer tussen tussentijdse sturing en de effectiviteit van outputsturing. Opmerkelijk is dat, tegengesteld aan de verwachting, het aantal benodigde uren voor beide processen significant toeneemt, naarmate gemeenten overgaan tot tussentijdse sturing. De hypothese dat tussentijdse sturing de effectiviteit van sturing verhoogt, zal dan ook voor beide processen verworpen moeten worden.

Uit de analyse blijkt, dat de contextvariabelen niet altijd een eenduidige impact hebben op de gerealiseerde effectiviteit. Zo lijkt de mate van overeenstemming $\left(\mathrm{H}_{1}\right)$ bij bouwaanvragen wel van belang, maar bij structuurvisies een geringer en zelfs een tegengesteld effect te hebben. De mate van eenduidigheid van outputformulering $\left(\mathrm{H}_{3}\right)$ heeft wel een eenduidige impact, maar tegengesteld aan de verwachting. Het inzicht $\left(\mathrm{H}_{2}\right)$ lijkt geen factor van betekenis voor de benodigde capaciteit. De politieke gevoeligheid $\left(\mathrm{H}_{4}\right)$ speelt bij structuurvisies juist weer een grotere rol dan bij bouwaanvragen. Het onderzoek toont dus geen eenduidige invloed aan van de contextvariabelen op de twee onderzochte processen.

Bevestigd kan worden dat processturing de effectiviteit niet bevordert (- 55 ). Zowel voor structuurvisies als voor bouwaanvragen is er een significant verschil geconstateerd. Opmerkelijk is, dat tussentijdse sturing $\left(\mathrm{H}_{7}\right)$ de benodigde capaciteit opvoert in plaats van reduceert.

Tabel 5 De relatie tussen processturing en de effectiviteit van outputsturing $(\mathrm{H5})$

\begin{tabular}{|l|l|l|}
\hline Processturing & Bouwvergunningen & Structuurvisies \\
\hline Afwezig (mean rank) & 10,8 & 12,0 \\
\hline Aanwezig (mean rank) & 22,5 & 25,0 \\
\hline $\begin{array}{l}\text { Asymp. Sig, Mann Whitney } \\
(p<0.05)\end{array}$ & 0,000 & 0,003 \\
\hline N & 30 & 27 \\
\hline
\end{tabular}


Tabel 6 De relatie tussen sturing ex ante en ex post en de effectiviteit van outputsturing ( $\mathrm{H6}$ )

\begin{tabular}{|l|l|l|}
\hline $\begin{array}{l}\text { Sturing } \\
\text { ex ante en ex post }\end{array}$ & Bouwvergunningen & Structuurvisies \\
\hline Afwezig (mean rank) & 19,0 & 18,9 \\
\hline Aanwezig (mean rank) & 14,2 & 12,3 \\
\hline $\begin{array}{l}\text { Asymp. Sig, Mann Whitney } \\
(p<0.05)\end{array}$ & 0,187 & 0,06 \\
\hline N & 30 & 27 \\
\hline
\end{tabular}

\section{Conclusies en discussie}

Bij de opkomst van New Public Management is ook het fenomeen outputsturing geïntroduceerd binnen de Nederlandse overheid. Onder outputsturing kan een sturingsvorm worden verstaan waarbij de productie van output leidend is voor de besluitvorming.

Het sturen op output levert in de praktijk van het openbaar bestuur de nodige problemen op. Men zal oog moeten houden voor de specifieke context, terwijl men tevens decentrale managers de mogelijkheid biedt processen naar eigen inzicht in te richten en te voeren.

In dit verband wordt in de literatuur gewezen op het belang van contextvariabelen voor de effectiviteit van sturing, maar wordt minder aandacht besteed aan het feit dat verschillende vormen van outputsturing kunnen bestaan, waarbij de ene vorm de opdrachtnemer meer vrijheidsgraden toekent dan de andere vorm. Immers wordt vrij universeel de indruk gewekt, dat slechts één vorm van outputsturing bestaat.

In dit onderzoek worden verschillende vormen van outputsturing onderscheiden. Outputsturing kan gecombineerd worden met inputsturing en processturing en kan op verschillende tijdstippen in de planning-en-controlcyclus worden ingezet. Naast deze sturingsvormen worden in dit onderzoek vier contextvariabelen onderscheiden: de mate van overeenstemming over de gewenste output van het proces, de mate waarin inzicht bestaat in het proces, de mate waarin output eenduidig wordt geformuleerd en de mate van politieke gevoeligheid.

De vraag is dan, in hoeverre contextvariabelen nu bepalend zijn voor de effectiviteit van outputsturing of dat deze effectiviteit mede bepaald wordt door de vorm van outputsturing waarvoor geopteerd wordt. Het onderzoek wijst uit, dat de contextvariabelen geen eenduidige impact hebben op de onderzochte processen. Verder kan vanuit het onderzoek de conclusie worden getrokken dat de sturingsvorm waarvoor geopteerd wordt, een grotere invloed heeft op de effectiviteit dan de context. Sommige vormen van outputsturing zijn effectiever dan andere
Tabel 7 De relatie tussen tussentijdse sturing en de effectiviteit van outputsturing (H7)

\begin{tabular}{|l|l|l|}
\hline Tussentijdse sturing & Bouwvergunningen & Structuurvisies \\
\hline Afwezig (mean rank) & 7,7 & 11,5 \\
\hline Aanwezig (mean rank) & 20,7 & 18,9 \\
\hline $\begin{array}{l}\text { Asymp. Sig, Mann Whitney } \\
(p<0.05)\end{array}$ & 0,00 & 0,022 \\
\hline N & 30 & 27 \\
\hline
\end{tabular}

vormen, ongeacht de context en de aard van het proces. Deze conclusie is opmerkelijk, gelet op de invloed die aan de context wordt toegeschreven.

Geconcludeerd kan worden dat processturing in vrijwel alle gevallen tot minder effectiviteit leidt. Daarnaast is tussentijdse sturing niet effectief. In de onderzochte processen was meer capaciteit nodig bij tussentijdse sturing. Deze conclusies staan haaks op de veel onderschreven wenselijkheid en noodzaak om tussentijds op processen te sturen (monitoring). De indruk ontstaat dat naarmate geopteerd wordt voor minder sturing (enkel vooraf en niet op processen), de sturingsvorm juist effectiever wordt.

Outputsturing zal rekening moeten houden met de context, maar daarnaast voldoende vrijheidsgraden moeten toekennen aan decentrale managers. Om adequaat te decentraliseren, zal geopteerd moeten worden voor de juiste sturingsvorm. Hoewel de invloed van de context ongetwijfeld aanwezig is, wijst dit onderzoek uit dat de effectiviteit van outputsturing voor een groot deel bepaald wordt door de sturingsvorm waarvoor geopteerd wordt. De sturingsvorm die zo veel mogelijk vrijheidsgraden toekent aan het decentrale management, biedt daarbij de beste basis voor effectief handelen. Paradoxaal gesteld kan het concern haar effectiviteit optimaliseren door zich zo min mogelijk met het desbetreffende proces in te laten.

Dr. R. J. Anderson is als lector Controlling verbonden aan de Hogeschool INHOLLAND.

Dr. H.L. Klaassen is werkzaam als universitair hoofddocent bij de Erasmus Universiteit Rotterdam, vakgroep

Bestuurskunde.

Dit artikel is gebaseerd op een onderzoek dat in april 2011 is gepresenteerd op het 15e congres van de International Research Society of Public Management in Dublin. De auteurs danken prof. dr. H.J. ter Bogt van de

Rijksuniversiteit Groningen voor zijn waardevolle suggesties. 


\section{Bijlage I Resultaten van onderzoek}

De resultaten zijn als volgt weer te geven:

\section{Tabel 8 De resultaten}

\begin{tabular}{|c|c|c|c|c|c|c|c|c|}
\hline \multirow[b]{2}{*}{$\begin{array}{l}\text { Bouwvergunning } \\
\text { No. gemeente }\end{array}$} & \multirow[b]{2}{*}{$\begin{array}{l}\text { Ambtelifke } \\
\text { capaciteit }\end{array}$} & \multicolumn{4}{|c|}{ Sturingsvorm } & \multicolumn{3}{|c|}{ Contextvariabelen } \\
\hline & & $\begin{array}{l}\text { Tijdstip } \\
\text { Input }\end{array}$ & $\begin{array}{l}\text { Tijdstip } \\
\text { Proces }\end{array}$ & $\begin{array}{l}\text { Tijdstip } \\
\text { Output }\end{array}$ & $\begin{array}{l}\text { Overeen- } \\
\text { stemming }\end{array}$ & Inzicht & $\begin{array}{l}\text { Eenduidig- } \\
\text { heid output }\end{array}$ & $\begin{array}{l}\text { Politieke } \\
\text { gevoeligheid }\end{array}$ \\
\hline 1 & 26 & V. A & $T$ & V, A & 1 & 2 & 3 & 3 \\
\hline 2 & 17 & V, A & & V, A & 2 & 2 & 1 & 2 \\
\hline 3 & 25 & V, T, A & V, T, A & V, T, A & 2 & 3 & 3 & 2 \\
\hline 4 & 15 & A & & A & 1 & 1 & 2 & 1 \\
\hline 5 & 22 & V, A & V & & 2 & 3 & 3 & 3 \\
\hline 6 & 29 & V, T, A & $\mathrm{T}$ & T, A & 2 & 3 & 2 & 2 \\
\hline 7 & 14 & V, A & & V, A & 1 & 2 & 1 & 1 \\
\hline 8 & 26 & V, A & $V, T$ & $\mathrm{~V}, \mathrm{~T}, \mathrm{~A}$ & 2 & 3 & 2 & 2 \\
\hline 9 & 28 & V & V, T & V & 2 & 2 & 3 & 2 \\
\hline 10 & 15 & V & & V & 2 & 3 & 2 & 3 \\
\hline 11 & 17 & V, A & & V, A & 2 & 3 & 1 & 1 \\
\hline 12 & 29 & T, A & T, A & $\mathrm{T}, \mathrm{A}$ & 1 & 2 & 2 & 2 \\
\hline 13 & 28 & V & T, A & V & 1 & 2 & 1 & 2 \\
\hline 14 & 14 & V, A & & V, A & 2 & 1 & 2 & 1 \\
\hline 15 & 18 & V & & A & 1 & 1 & 2 & 1 \\
\hline 16 & 22 & V, T, A & & V, T, A & 1 & 2 & 3 & 3 \\
\hline 17 & 27 & V, A & $V, T$ & V, A & 1 & 2 & 3 & 2 \\
\hline 18 & 29 & T, A & & T, A & 1 & 2 & 3 & 1 \\
\hline 19 & 14 & $\mathrm{~V}, \mathrm{~T}$ & & A & 2 & 3 & 1 & 3 \\
\hline 20 & 11 & A & & A & 2 & 3 & 1 & 1 \\
\hline 21 & 28 & V, A & T, A & V, A & 1 & 1 & 2 & 2 \\
\hline 22 & 16 & V, T & & V. A & 2 & 3 & 1 & 2 \\
\hline 23 & 25 & V. A & $T$ & V, A & 1 & 1 & 3 & 3 \\
\hline 24 & 24 & T, A & & $V, A, T$ & 1 & 1 & 3 & 1 \\
\hline 25 & 29 & T, A & & $\mathrm{T}, \mathrm{A}$ & 1 & 1 & 3 & 1 \\
\hline 26 & 14 & V & & A & 2 & 3 & 1 & 2 \\
\hline 27 & 16 & V, A & & V, A & 2 & 3 & 2 & 1 \\
\hline 28 & 23 & T, A & & V, T, A & 2 & 1 & 2 & 3 \\
\hline 29 & 29 & T, A & T, A & $\mathrm{T}, \mathrm{A}$ & 1 & 1 & 3 & 2 \\
\hline 30 & 14 & V, A & & V, A & 2 & 3 & 3 & 2 \\
\hline
\end{tabular}




\begin{tabular}{|c|c|c|c|c|c|c|c|c|}
\hline $\begin{array}{l}\text { Structuurvisie } \\
\text { No. gemeente }\end{array}$ & $\begin{array}{l}\text { Ambtelifke } \\
\text { capaciteit }\end{array}$ & $\begin{array}{l}\text { Tijdstip } \\
\text { Input }\end{array}$ & $\begin{array}{l}\text { Tijdstip } \\
\text { Proces }\end{array}$ & $\begin{array}{l}\text { Tijdstip } \\
\text { Output }\end{array}$ & $\begin{array}{l}\text { Overeen- } \\
\text { stemming }\end{array}$ & Inzicht & $\begin{array}{l}\text { Eenduidig- } \\
\text { heid output }\end{array}$ & $\begin{array}{l}\text { Politieke } \\
\text { gevoeligheid }\end{array}$ \\
\hline 1 & 1355 & V, A & & V, A & 1 & 3 & 2 & 1 \\
\hline 2 & 1400 & V, A & & A & 1 & 2 & 2 & 1 \\
\hline 3 & 1500 & A & & V, A & 2 & 2 & 1 & 1 \\
\hline 4 & 2315 & T, A & $\mathrm{T}$ & T, A & 2 & 1 & 3 & 1 \\
\hline 5 & 964 & V & & $\mathrm{V}, \mathrm{A}$ & 2 & 1 & 3 & 2 \\
\hline 6 & 4315 & $\mathrm{~T}, \mathrm{~A}$ & T, A & T, A & 1 & 3 & 2 & 1 \\
\hline 7 & 1498 & V & & A & 2 & 1 & 3 & 1 \\
\hline 8 & 1250 & V, T, A & & V, A & 1 & 3 & 1 & 1 \\
\hline 9 & 651 & A & & A & 1 & 2 & 1 & 2 \\
\hline 10 & 416 & V, A & & V, A & 2 & 2 & 1 & 3 \\
\hline 11 & 1498 & V, T, A & & V, T, A & 2 & 2 & 1 & 2 \\
\hline 12 & 986 & V, A & & V, A & 1 & 1 & 2 & 2 \\
\hline 13 & 1748 & $V, A$ & V, A & $\mathrm{V}, \mathrm{A}$ & 2 & 1 & 2 & 1 \\
\hline 14 & 684 & V, A & & V, A & 2 & 3 & 1 & 2 \\
\hline 15 & 987 & V, T, A & & $V, T, A$ & 1 & 1 & 3 & 1 \\
\hline 16 & 1345 & V, A & & V. A & 1 & 2 & 1 & 1 \\
\hline 17 & 666 & $V, T, A$ & & $V, T, A$ & 1 & 1 & 3 & 1 \\
\hline 18 & 1847 & T, A & & $\mathrm{T}, \mathrm{A}$ & 2 & 1 & 3 & 2 \\
\hline 19 & 954 & A & & $A$ & 1 & 3 & 1 & 2 \\
\hline 20 & 658 & V, A & & $V, A$ & 1 & 2 & 2 & 2 \\
\hline 21 & 597 & V, A & & $V, A$ & 2 & 3 & 2 & 1 \\
\hline 22 & 1594 & T, A & & $\mathrm{T}, \mathrm{A}$ & 2 & 1 & 1 & 1 \\
\hline 23 & 1763 & V, A & $V, A$ & V, A & 2 & 3 & 3 & 1 \\
\hline 24 & 635 & V & & V, A & 1 & 2 & 3 & 3 \\
\hline 25 & 555 & V, A & & V & 2 & 2 & 2 & 3 \\
\hline 26 & 798 & V, A & & V, A & 1 & 1 & 2 & 2 \\
\hline 27 & 1367 & T, A & & $\mathrm{T}, \mathrm{A}$ & 1 & 1 & 3 & 1 \\
\hline
\end{tabular}

In de eerste kolom worden de gemeenten weergegeven, in de tweede de bestede ambtelijke capaciteit in productieve uren. Kolom 3, 4 en 5 geven het tijdstip van sturing aan voor input, proces respectievelijk output ( $V=$ vooraf, $T=$ tussentijds en $A=$ achteraf). De laatste vier kolommen geven de scores op de contextvariabelen weer. Voor overeenstemming, inzicht en eenduidigheid wordt een score toegekend van 1 (weinig overeenstemming, inzicht of eenduidigheid) tot 3. Bij politieke gevoeligheid wordt een 3 toegekend als het proces weinig gevoelig ligt, een 1 als het proces zeer politiek gevoelig ligt.

\section{Noten}

Onder output wordt doorgaans de prestatie van een overheidsdienst verstaan. Effect verwijst dan naar het maatschappelijk effect voor zover dat is toe te rekenen aan deze prestatie.

2 Het oorspronkelijke onderzoek neemt meer variabelen in beschouwing, maar ten behoeve van dit artikel worden slechts twee sturingsvariabelen gepresenteerd.
De context waarbinnen deze twee processen verlopen, verschilt naar verwachting aanzienlijk. Daarnaast worden structuurvisies kwalitatief getoetst door de provincie, terwijl ook bouwbeschikkingen getoetst kunnen worden. Bovendien zijn enkel de bouwaanvragen uit de reguliere categorie geselecteerd voor dit onderzoek.
Nederland kent ten tijde van het onderzoek 121 middelgrote gemeenten. 57 daarvan hebben deelgenomen aan het onderzoek. Hoewel deze respons lager is dan $50 \%$, is het aantal groot genoeg voor een statistische bewerking van de onderzoeksresultaten. 


\section{Literatuur}

Aardema, H. (2005), Stille waarden: een reflectie op overnormering in publiek management, Heerlen: Open Universiteit. - Anderson, R.J. (2006), Tussen schakelen en switchen, Enschede: Gildeprint.

- Blank, J.L.T. (2010), Principes van productiviteitsmeting, Maastricht: Shaker Publishing BV.

- Bogt, H.J. ter (2004), Politicians in search of performance information? Survey research on Dutch aldermen's use of performance information, Financial Accountability and Management, vol. 20, no. 3, pp. 221-252.

- Bogt, H.J. ter (2008), Recent and future management changes in local government: continuing focus on rationality and efficiency?, Financial Accountability and Management, vol. 24, no. 1, pp. 31-57.

- Bouckaert, G. en J. Halligan (2008), Managing performance, International comparisons, Oxon: Routledge.

- Bordewijk, P. en H.L. Klaassen (2000), Wij laten ons niet kennen, Den Haag: VNG.

- Bozeman, B. (2007), Public values and public interest, counterbalancing economic individualism, Washington, D.C.: Georgetown University Press.

- Brignall, S. en S. Modell (2000), An institutional perspective on performance measurement and management in the 'New Public Sector', Management Accounting Research, vol. 11, no. 3, pp. 281-306.

- Bruijn, H. de (2001), Prestatiemeting in de publieke sector, Utrecht: Lemma.

- Caiden, N. (2010), Challenges confronting contemporary public budgeting: retrospectives and prospectives from Allen Schick, Public Administration Review, vol. 70, no. 2, pp. 202210.
Christiaens, J. en J. Rommel (2008), Accrual accounting reforms: only for businesslike (parts of) governments, Financial Accountability and Management, vol. 24, no. 1, pp. 59-75.

Dooren, W. van, G. Bouckaert en J. Halligan (2010), Performance management in the public sector, London: Routledge.

- Elsacker, W.J. van, H.J. ter Bogt en G.J. van Helden (2008), Role variations of performance measurement in Dutch local Government, Irish Accounting Review, vol. 15, no. 1, pp. 51-72.

- Groot, T. en T. Budding, (2008), New Public Management's current issues and future prospects, Financial Accountability and Management, vol. 24, no. 1, pp. 1-13.

- Helden, G.J. van, en A. Johnsen (2002), A comparative analysis of the development of performance-based management systems in Dutch and Norwegian local government, International Public Management Journal, vol. 5 , no. 1, pp. 75-95.

- Herweijer, M. (2010), Effecten van prestatiebekostiging, in: D. Verlet en C. Devos (redactie), Efficiëntie en effectiviteit van de publieke sector in de weegschaal, Studiedienst van de Vlaamse Regering, Sint-Niklaas: Room.

- Hood, C. (1991), A public management for all seasons?, Public Administration, vol. 69, no. 1, pp. 3-19.

- Hood, C. (1995), The New Public Management in the 1980's: variations on a theme, Accounting, Organizations and Society, vol. 20, no. 2/3, pp. 93-109.

Hood, C. en G. Peters (2004), The middle aging of New Public Management: Into the age of paradox?, Journal of Public Administration Research and Theory, vol. 14, no. 3, pp. 267281.
Klaassen, H.L., R.J. Anderson en H. Maks (2010), Doelmatigheid: puzzel voor het openbaar bestuur, in: D. Verlet en C. Devos (redactie), Efficiëntie en effectiviteit van de publieke sector in de weegschaal, Studiedienst van de Vlaamse Regering, Sint-Niklaas: Room.

- Klijn, A., J. de Ruiter en M. Herweijer (2006), Evaluatie ASV: onderzoek naar de doelmatigheid en doeltreffendheid van de algemene subsidieverordening 2004, Assen: Provincie Drenthe.

- Merchant, K.A. en W.A. van der Stede (2003), Management control systems: Performance measurement, evaluation and incentives, Harlow: Prentice Hall.

- Moynihan, D.P. (2008), The dynamics of performance management: constructing information and reform, Washington D.C.: Georgetown University Press.

Pollitt, C. (1993), Managerialism and the public services: Cuts or cultural change in the 1990s?, Oxford: Basil Blackwell.

- Pollitt, C. en G. Bouckaert (2004), Public management reform: a comparative analysis, Oxford: Oxford University Press.

- Pollitt, C., X. Girre, J. Lonsdale, R. Mul, H. Summa en H. Warness (1999), Performance or compliance? Performance audit and public management in five countries, Oxford: Oxford University Press.

- Veld, R.J. in 't, en P. van der Knaap (1994), Dynamische bestuurskunde, Den Haag:

Phaedrus.

- Terry, L.D. (1998), Administrative leadership, neo-managerialism, and the Public Management movement, Public Administration Review, vol. 58, no. 3, pp. 194-200.

- Whalen, E. L. (1991). Responsibility center budgeting: An approach to decentralized management for institutions of higher education. Bloomington, Indiana University Press. 